\title{
Turf Yellowing Disease in Paspalum vaginatum (Turf Grass): Identification of Causative pathogen and Chemical Control
}

\author{
A. G. I. Malkanthi, R. A. S. Perera ${ }^{2}$ and M. L. M. C. Dissanayake ${ }^{1}$
}

SHORT COMMUNICATION

Received: $8^{\text {th }}$ October 2015 / Accepted : 25 th December 2015

\begin{abstract}
Symptoms of an unknown foliar yellowing have been observed in Paspalum vaginatum in Kandy District of Sri Lanka since 2013. Affected leaves initially exhibit yellowing of leaves followed by browning downwards from the leaf tip. Since there is no previous record of the disease in Sri Lanka, no control measures have been established. Thus, the aim of this study was to isolate and identify the causal agent of turf yellowing disease in commercial turfs in Mawanella, Pearadeniya and Kandy area Sri Lanka and to evaluate the efficacy of available fungicides against pathogen. Pathogens were isolated from infected $P$. vaginatum and identified using macroscopic and microscopic features and concluded that the disease found in P. vaginatum was caused by Curvularia trifolii. Effect of synthetic fungicide Captan, Chlorothalonil and Sulphur against the isolates was tested both invitro and in-vivo conditions. The isolates was consistently reisolated from diseased grasses, but not from health controls, demonstrating that the isolates was pathogenic to turf grass. The effects of all concentrations of all the fungicides used (except Sulphur in recommend dose) with regards to mycelia growth were significantly $(p=0.05)$ different from the control. The highest concentration of Captan $(40 \mathrm{mg} / 10 \mathrm{ml})$ and recommend dose of Chlorothalonil $(30 \mu \mathrm{l} / 10 \mathrm{ml})$ was the most efficient fungicide against $C$. trifolii. In-vitro and in-vivo respectively. The present study concludes and Chlorothalonil was the most effective among the tested fungicides for the control of $C$. trifolii causing the turf yellowing disease in field condition.
\end{abstract}

Keywords: captan, chlorothalonil, curvularia, paspalum vaginatum, sulphur

\section{INTRODUCTION}

Paspalum vaginatum is a prostrate, perennial turf grass in Poaceae family and the Genus Paspalum. It is a native to America, and grows in tropical and subtropical regions worldwide. Fine-textured ecotypes used for golf courses, athletic fields, commercial lawns, parks, sod farms, and other landscape areas (Brosnan and Deputy, 2008).

At present a disease similar to turf yellowing disease has been reported in $P$. vaginatum by commercial turf producers in Mawanella, Pearadeniya and Kandy area in Sri Lanka. Symptoms first appear as yellowing of mature leaves and then browning downwards from the leaf tip. Leaf spots occur with symptoms most severe being on older, senescing leaves. Infected area eventually turn straw colored and makes dry patches in turf. Roots, stolons and rhizomes may also get affected. The disease severity is higher under heat stress, excessive rainfall, pest attack, compacted soil and poor drainage conditions.

2 Floriculture Research and Development unit, National Botanic Gardens, Peradeniya, Sri Lanka. 
Due to this disease, the quality of turf is lost and the demand for the turf is reduced. These yellow patches are none appealing sight and it disturbs the uniform appearance of turf products. The cause responsible for the above condition has not been identified and no effective control is available.

Synthetic fungicides areavailable for commercial level turf grass management at present. Many of the newest fungicides are least toxic to humans, birds and fish and have extremely specific modes of action (Han, 2004). Captan, Chlorothalonil and Sulphur are contact fungicides which are recommended for the control of foliar diseases in turf grass (non-pasture) (Gould, 2012). Unlike systemic fungicides, contact fungicides are not transported through a plant's vascular system and only provide a protective barrier on the leaf and kill fungi by targeting specific enzymes or biochemical processes before they can infect the plant. Therefore contact fungicides are commonly recommended for treating foliar diseases in turf grass (Han, 2004).

Thus present study was conducted with the objectives of identifying the causative organism / organisms responsible for this disease and to confirm the pathogenicity, and to screen some synthetic fungicides (Captan, Chlorothalonil and Sulphur) against the causative pathogen.

\section{MATERIALS AND METHODS}

\section{Pathogen isolation and identification}

Disease infected grass were collected from turf farms in Kandy. Leaf sections were surface disinfested in $1 \%$ sodium hypochlorite solution for one minute followed by $70 \%$ ethanol for two minutes and then rinsed thrice in sterilized water. Then blotted dry a $\mathrm{d}$ plated on potato dextrose agar (PDA) containing $50 \mathrm{mg} / 1$ streptomycin. Plates were incubated at the temperature of 27 $\left(+\right.$ or $-2{ }^{\circ} \mathrm{C}$ ). After 7 days the fungal isolates appearing on the leaf pieces were identified and transferred to PDA and SNA (Synthetic Nutrient
Agar) slants for purification. Pathogenicity of all isolates was tested by Koch's postulation and re-isolated the pathogen on PDA. Microscopic features of isolated organism were observed 7 days after incubation in SNA medium. Culture plates were directly observed through light microscope with 40x, 100x and 400x magnification and morphological features were identified and then causative pathogen was recognized using illustrated keys (Kaushal and Singh, 2010).

\section{Bioassay}

The causative pathogen was screened against synthetic fungicides to determine their efficacy. Agar overlay technique was applied to the cultivation of test organism on a medium containing the test fungicide and then measuring its growth (Yumura et al., 1984). Recommended as well as higher doses of three fungicides namely Captan, Chlorothalonil and Sulphur $(80 \%)$ were screened against isolated pathogen.

The respective dose of each fungicide solution (1ml) was added to $9 \mathrm{ml}$ of autoclaved PDA medium in a petri dish at about $40-50{ }^{\circ} \mathrm{C}$. Control treatment was maintained without any fungicide. A $5 \mathrm{~mm}$ mycelium agar disc of isolate was placed on the center of agar medium and incubated at room temperature of $27\left(+\right.$ or $\left.-2{ }^{\circ} \mathrm{C}\right)$. Each treatment was replicated thrice. After 7 days, the diameter of the fungal colony was recorded and percentage mycelium inhibition was calculated using the following formula.

\section{\% of inhibition = Diameter of control colony - Diameter of the treated colony ${ }^{*} 100$ Diameter of contiol colony}

The experiment was set up as a completely randomized design (CRD) and analysis of variance (ANOVA) was performed using SAS 9.0 statistical software package. The mean separation was done by Duncan's multiple range test at $\mathrm{P} \leq 0.05$. 


\section{Field Experiment}

Field experiment was carried out in open field at National Botanic Gardens, Peradeniya, Sri Lanka. Usual day temperature of the site is $25^{\circ} \mathrm{C}-28^{\circ} \mathrm{C}$. The average humidity is $65 \%$ $70 \%$, annual rainfall is $2000-2500 \mathrm{~mm}$ and shade level is $70 \%$. Elevation of the location is $500 \mathrm{~m}$ above mean sea level.

Healthy planting material of $\mathrm{P}$. vaginatum were planted on sterilized soil media with top soil, compost, coir dust, sand in 1:1:1:1 ratio in black polythene bags with $20 \mathrm{~cm}$ diameter and $5 \mathrm{~cm}$ height. Two weeks old healthy plants were sprayed with conidial suspension of $1 \times 10^{6}$ conidia / $\mathrm{ml}$ of the isolates. The recommend doses of fungicides were fallowed as treatments as Captan $3000 \mathrm{~g} / \mathrm{ha}$ (Dilution concentration $250 \mathrm{mg} / 50 \mathrm{ml}$ ), Sulphur $800 \mathrm{~g} /$ ha (Dilution concentration $100 \mathrm{mg} / 50 \mathrm{ml}$ ) and Chlorothalonil $1000 \mathrm{ml} / \mathrm{ha}$ and Chlorothalonil $1000 \mathrm{ml} / \mathrm{ha}(150 \mathrm{ul} / 50 \mathrm{ml})$

There were four treatments and six replicates. Replicates were set up with $3 \mathrm{~m}$ x $3 \mathrm{~m}$ spacing. Treatment application was started at one week after planting and repeated once a week. All agronomic practices were done according to the recommendation and all other factors were managed uniformly. Experiment was set up in a randomized complete block design (RCBD). Disease severity was rated daily for five days on a 1 to 10 scale using a slight modification of a previously published method (Falloon, 1975), where $0=$ dead turf, $1=90 \%$ Disease infection, $2=80 \%$ Disease infection, $3=70 \%$ Disease infection $.4=60 \%$ Disease infection, $5=50 \%$ $6=40 \%$ Disease infection, $7=30 \%$ Disease infection, $8=20 \%$ Disease infection, $9=910 \%$ Disease infection and $10=$ best quality. Analysis of variance was carried by Friedman test in MINITAB $^{\circledR} \quad$ Release 14.1(2003) Statistical Software.

\section{RESULTS AND DISCUSSION}

\section{Symptoms and prevalence of the disease}

An unusual disease of seashore Paspalum was observed in commercial turf producers in Mawanella, Pearadeniya and Kandy area in Sri Lanka during the warm period of 2013 and gradually became more serious. In worm weather, infected leaves appear as yellowing of mature leaves and then browning downwards from the leaf tip. Leaf spots occur with symptoms most severe being on older, senescing leaves. Infected area eventually turn straw colored and makes dry patches in turf (Figure 01). Roots, stolons and rhizomes may also get affected. The disease severity is higher under heat stress, excessive rainfall, pest attack, compacted soil and poor drainage conditions. Hodges et al., 1979 reported that Curvularia spp. are only associated with more severe disease problems at higher temperatures $\left(>25^{\circ} \mathrm{C}\right)$ or when plant tissue is older and/or senescent. This study also found disease severity was significantly higher with increasing temperature.

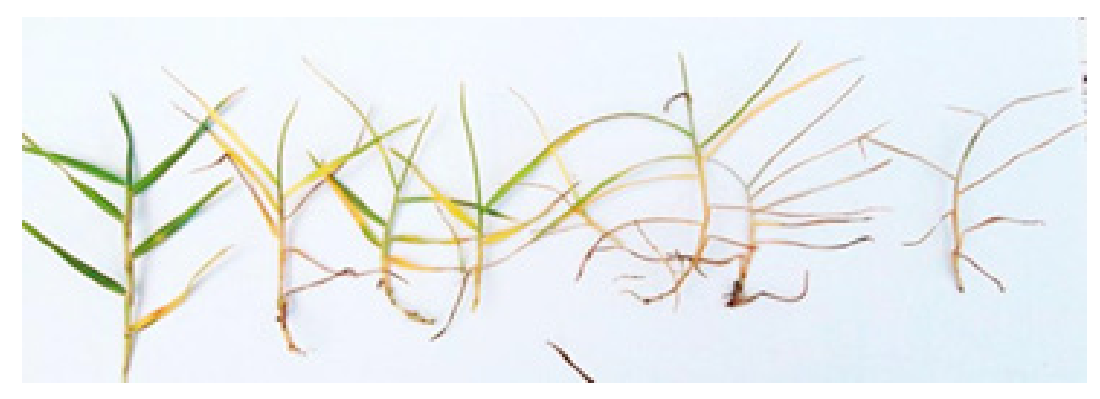

Figure 01: Disease symptoms development of the shoots of $P$. vaginatum. 


\section{Identification of pathogen}

Symptoms were reproduced on all grass inoculated with the fungal isolates. Control plants had no symptoms. The same fungus was consistently re-isolated from all diseased plants, but not from healthy grasses (the control), demonstrating that isolates were pathogenic to $P$. vaginatum. The disease causing pathogen was isolated and identify as a fungal species which was clearly growing from the area where the leaf yellowing condition was percent in inoculated leaf parts on PDA.

Particular fungus produced whitish colonies in initial stage and then colonies becoming grayish black on the surface and dark brown to black on the reverse with irregular margins on PAD medium. Pure culture colony was woolly in texture on PDA medium with irregular margin and colour of the colony was white to pinkish gray initially and turned to olive brown and black as the colony matured. And when inoculated pure culture on SNA, colony was observed as slow growing fine texture, whitish mycelium after 5-9 days and turn grayish on the surface after 10- 14 days (Figure 02, A,B,C,D).

Fungal Isolates produced a filamentous vegetative body within 7 days in SNA medium. Mycelium was septate and the fungus produced asexual spores (conidia) within 7-10 days. Conidia were produced at the tip of conidiophores. Conidiophores were both simple and branched and they were bent at the points where the conidia originate (geniculate growth) and produced conidia in sympodial order. Shapes of conidia varied into straight, pyriform, ellipsoidal and some were often gently curved having 3- 4 septa. The septa are transverse and divided each conidium into multiple cells. The central cell was darker and enlarged compared to the end cells in the conidia. (Figure 02, E,F,G,H).

According to the observation of macroscopic and microscopic characteristics the causal agent of turf yellowing disease was confirmed as a Curvularia trifolii as described by; Sutton et al ., 1998, St-Germain and Summerbell, 1996, Kaushal and Singh, 2010 and Falloon, 1975.

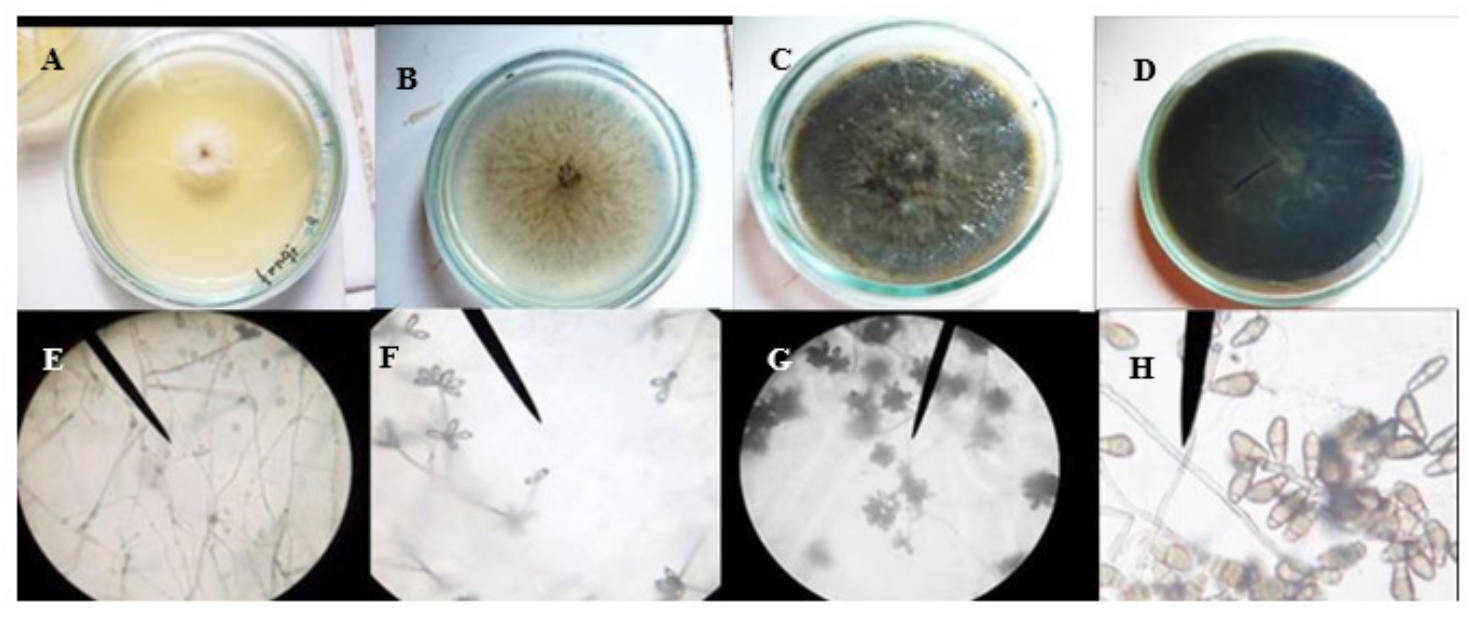

Figure 02: Macroscopic and Microscopic features of isolated fungus

A. Pure culture of Curvularia on SNA (2 days), B. Pure culture of Curvularia on SNA(14 days), C. Pure culture of Curvularia on PDA -upper side (7 days), D. Pure culture of Curvularia on PDA- reverse side (14 days), E. Mycelium of Curvularia (magnification 400x), F. Hyphae and branched conidiophores of Curvularia (400x), G. Conidiophore bearing single and multicellular conidia (400x) H. Curvularia conidiophore with geniculate (bent) apical end bearing sympodially placed, curved, multicellular conidia $(400 \mathrm{x}, 5 \mathrm{x})$ 


\section{In-vitro evaluation of synthetic fungicide against the Curvularia sp.}

There was a significant difference in fungicidal potential among the three test fungicides against the Curvularia trifolii (Table 01). Percentage of mycelium growth inhibition increased, with the increasing dosage of fungicides. Among the three fungicides, Captan was found to be the most effective where all the employed doses significantly suppressed the fungal mycelium growth. There was $72.37 \%, 79.93 \% 80.58 \%$ and mycelia growth inhibition due to application of recommended $(20 \mathrm{mg} / 10 \mathrm{ml})$ and higher doses $(30 \mathrm{mg} / 10 \mathrm{ml}, 40 \mathrm{mg} / 10 \mathrm{ml})$ of this fungicide. Chlorothalonil was found to be the second most effective fungicide against the target fungal species. The recommended dose $(30 \mu \mathrm{l} / 10 \mathrm{ml})$ and higher dose of this fungicide $(60 \mu \mathrm{l} / 10 \mathrm{ml})$ resulted in $35.13 \%$ and $44.68 \%$ mycelium growth inhibition respectively. Both doses significantly reduced fungal growth compared to the control. The effect of recommended dose of Sulphur $(50 \mathrm{mg} / 10 \mathrm{ml})$ was insignificant. It was found ineffective in suppressing the fungal biomass. The higher dose $(100 \mathrm{mg} / 10 \mathrm{ml})$ of this fungicide significantly enhanced fungal biomass as compared to control.

\section{In-vivo evaluation of the effect of synthetic fungicide against the Curvularia}

Figure 03 shows the results of the disease severity index for each treatment in relation to time. Disease severity was changed with time. Effect of Captan and Chlorothalonil was significantly different from control test on quality of $P$. vaginatum. There was no significant difference between the Sulphur treatment and the control. Chlorothalonil was most effective on suppressing the disease on turf under filed condition and the turf quality was changed between 10-8 scales on Chlorothalonil treated turf. Turf quality was changed between 10-6 scales on Captan treated turf. Sulphur exhibited week action against the pathogen and this was similar to the control and turf quality which changed between 10-5 scales.

Chlorothalonil is widely used to control fungal diseases and reduced fungal intracellular glutathione molecules to alternate forms which cannot participate in essential enzymatic reactions, ultimately leading to cell death.

Table 01: Colony diameter $(\mathrm{mm})$ and inhibition percentage of Curvularia sp. 7 days after treated with different fungicides

\begin{tabular}{lccc}
\hline \multicolumn{1}{c}{ Treatment } & Concentration & Mean colony diameter (mm) & Percentage of inhibition (\%) \\
\hline Control & no fungicide & 70 & $0^{\mathrm{a}}$ \\
Captan & $20 \mathrm{mg} / 10 \mathrm{ml}(\mathrm{T} 1 \mathrm{C} 1)$ & 19 & $72.37^{\mathrm{e}}$ \\
& $30 \mathrm{mg} / 10 \mathrm{ml}(\mathrm{T} 1 \mathrm{C} 2)$ & 14 & $79.93^{\mathrm{f}}$ \\
& $40 \mathrm{mg} / 10 \mathrm{ml}(\mathrm{T} 1 \mathrm{C} 3)$ & 13 & $80.58^{\mathrm{f}}$ \\
Chlorothalonil & $30 \mu \mathrm{l} / 10 \mathrm{ml}(\mathrm{T} 2 \mathrm{C} 1)$ & 45 & $35.13^{\mathrm{d}}$ \\
& $60 \mu \mathrm{l} / 10 \mathrm{ml}(\mathrm{T} 2 \mathrm{C} 2)$ & 39 & $44.68^{\mathrm{c}}$ \\
Sulphur & $50 \mathrm{mg} / 10 \mathrm{ml}(\mathrm{T} 3 \mathrm{C} 1)$ & 70 & $0^{\mathrm{a}}$ \\
& $100 \mathrm{mg} / 10 \mathrm{ml}(\mathrm{T} 3 \mathrm{C} 2)$ & 60 & $13.70^{\mathrm{b}}$ \\
\hline
\end{tabular}

Values in a row having different superscripts are significantly different according to the Duncan's multiple range test at $\mathrm{P} \leq 0.05$. 


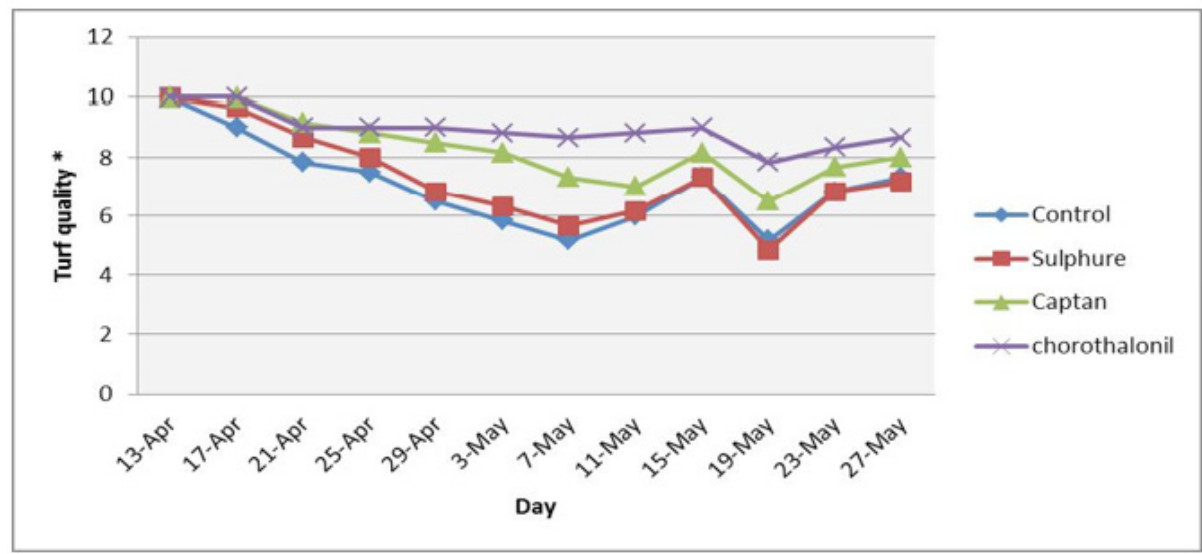

Figure 03: Evaluation of turf quality based on diseases severity index under different fungicide treatment

Chlorothalonil provides excellent spreading and sticking power for extended coverage on the crown and sheath of grass blades or ornamental plants for unsurpassed protection, even after heavy rains or watering. (Daconil action fungicide, 2011).

Chlorothalonil has been recommended for the control of the Curvularia blight in the filed condition (UC Pest Management Guidelines, 2009). Captan is a non-specific thiol reactant with protective and curative action that works by inhibiting respiration of numerous species of fungi and bacteria (Edwards et al., 1991). Different concentration of Captan has successfully been tested against the Curvularia spp in-vitro (Mandokhot and Chaudhry, 2005). Sulfur creates a plant protective coating on the surface of a plant that prevents the spore germination of certain plant diseases. (The Agrochemicals Handbook, 1983) In Sulphur, moderate to poor growth was seen in Curvularia lunata (Dandge, 2012).

\section{CONCLUSIONS}

The causative pathogen of the turf yellowing disease in P. vaginatum is a Curvularia trifolii. Chlorothalonil was efficient under field condition to control the disease.

\section{REFERENCES}

Agro chemicals Handbook, (1983). Douglas Hartley and Hamish Kidd, The Royal Society of Chemistry, The University, Nottingham, England.

Brosnan ,J.T. and Deputy, J., (2008). Seashore Paspalum, Department of Tropical Plant and Soil Sciences Turf Management.

Daconil action fungicide, (2011). Steve McDonald, Turfgrass Disease Solutions, Syngenta, Available from:www.syngentacropprotection.com/assets/.../daconil_techsheet.pdf

Dandge V. S, (2012). Effect of some fungicide on growth (in mm) of Curvularia lunata, Journal of Experimental Sciences 3(3): pp. 19-20. 
Edwards I.R., Ferry D.G. and Temple W.A., (1991). Fungicides and Related Compounds.In: Handbook of Pesticide Toxicology, Hayes WS Jr. and Laws ER, Jr., (Eds.); Academic Press, Inc. New York. pp. 1410-1415.

Falloon, R. E. (1975). Curvularia trifolii as a high-temperature turfgrass pathogen. New Zealand Journal of Agricultural Research. 19: pp. 243-248. http://dx.doi.org/10.1080/00288233.19 76.10426773

Gould A., (2012). Disease control recommendation for ornamental crops Rutger. NJAES Cooperative Extension. New Jersey Agricultural Experiment Station. US. Publication.

Han D.Y. and Hangan A.K., (2004). Fungicides for control of turf grass diseases. Agronomy series timely information. Agriculture \& Natural Resources. Department of Agronomy and Soils. Auburn University.

Hodges, C. F., and Madsen, J. P. (1979). Leaf senescence as a factor in the competitive and synergistic interactions of Dreschlera sorokiniana and Curvularia geniculata on Poa pratensis. Canadian Journal of Botany 57: pp. 1706-1711. http://dx.doi.org/10.1139/b79209

Kaushal A. and Singh R., (2010).Some species of Curvularia from surrounding areas of Upper and Lower lakes of Bhopal. Nanobiotechnica Universale. 1(2), pp. 159-162.

Mandokhot, A.M., and Chaudhary, K.C.B., (2005). Control of Leaf spot of maize caused by Curvularia species, Departmet of Mycology and Plant Pathology, Faculty of Agriculture, Banaras Hindu University. 37(6) pp. 500-505.

St-Germain, G., and Summerbell, R., (1996). Identifying Filamentous Fungi, A Clinical Laboratory Handbook, $1^{\text {st }}$ ed, Star Publishing Company, Belmont, California.

Sutton, D. A., Fothergill, A. W. and Rinaldi, M. G., (1998). Guide to Clinically Significant Fungi $\left(1^{\text {st }} \mathrm{ed}\right)$, Williams \& Wilkins, Baltimore.

Yumura, S., Mori, H., and Fukui, Y., (1984). Localization of actin and myosin for the study ofamoeboid movement in Dictyostelium discoideum using improved immunofluorescence. The Journal of Cell Biology. 99, pp. 894-899. http://dx.doi.org/10.1083/jcb.99.3.894

UC Pest Management Guidelines, (2009). How to Manage Pests, Statewide IPM Program, Agriculture and Natural Resources, University of California. 